\title{
Diatoms as indicators of water quality in the Jukskei-Crocodile river system in 1956 and 1957, a re-analysis of diatom count data generated by BJ Cholnoky
}

\author{
JC Taylor ${ }^{1 *}$, WR Harding ${ }^{2}$, CGM Archibald ${ }^{3}$ and L van Rensburg ${ }^{1}$ \\ ${ }^{1}$ School of Environmental Sciences and Development, Division Botany, North-West University (Potchefstroom Campus), \\ Private Bag X6001, Potchefstroom 2520, South Africa \\ ${ }^{2}$ DH Environmental Consulting, PO Box 5429, Helderberg 7135, South Africa \\ ${ }^{3}$ KZN Aquatic Ecosystems, 18 Ashcombe Park, 150 Prospect Hall Road, Durban North 4051, South Africa
}

\begin{abstract}
South Africa has a long legacy of diatom research. The eminent diatomist Dr BJ Cholnoky spent much of his working life examining and enumerating diatom communities found in Southern Africa. Most if not all of Cholnoky's collected diatom material in the form of mounted material on glass slides accompanied by diatom analysis sheets is stored in the South African Diatom Collection currently housed at the CSIR in Durban. As Cholnoky only employed enumeration methods yielding a margin of error of $2 \%$ or less, Cholnoky's results should provide an accurate reflection of the structure of the diatom communities that he examined. It is the aim of the present study to demonstrate the value of these historical diatom analyses for inferring past water quality conditions using the diatom-based index method. Data for the Jukskei-Crocodile River system were obtained from the South African Diatom Collection for the period 1956/1957. The nomenclature of the diatoms listed on Cholnoky's data sheets was modernised and the data then entered into OMNIDIA v3.1. Diatom index scores generated from OMNIDIA v3.1 were in general in agreement with Cholnoky's own assessment of water quality (especially with reference to organic pollution). It is concluded that the diatom analysis records housed in the South African Diatom Collection constitute a valuable resource for the assessment of past conditions of rivers and streams.
\end{abstract}

Keywords: BJ Cholnoky, historical diatom analyses, diatom indices, historical water quality

\section{Introduction}

Over many years the work of Dr BJ Cholnoky provided an invaluable contribution to the knowledge of the taxonomy and ecology of diatom species he encountered in a variety of southern African habitats. Cholnoky's ecological work attempted to provide a reflection of water quality based on the specific pollution tolerances of diatom species, and especially to nitrogenous compounds. In addition Cholnoky was one of the first people to predict $\mathrm{pH}$ of a water-body based on its diatom community (Cholnoky, 1958). Cholnoky was only able to relate several key species from a particular diatom community to different pollutants; later workers have had the luxury of using statistical techniques such as correspondence analysis (Ter Braak and Prentice, 1988) to determine the relationships between the abundances of all diatom species encountered in a certain community and the chemical composition of their aquatic environment. Consequently inferred tolerances can be assigned to diatom species for a whole range of water quality variables rather than just for nitrogen or $\mathrm{pH}$.

When Cholnoky's (1968) definitive work on the diatoms Die Ökologie Der Diatomeen in Binnengewässern is examined it is noted that Cholnoky painstakingly dealt with all practical aspects relevant to diatom ecological studies. He first stressed that any person studying ecology should have a sound taxonomical

\footnotetext{
* To whom all correspondence should be addressed.

调 +2718 299 4305; fax: +2718 299 2504;

e-mail: plbjct@.puk.ac.za

Received 7 July 2004; accepted in revised form 21 December 2004.
}

background; secondly he carefully determined margins of error for diatom analysis. Most importantly he tested various counting procedures and determined whether different slides from the same site need to be counted to generate an accurate result, how many individual cells should be counted and the manner in which diatom cells should be counted. Cholnoky only employed methods yielding a margin of error of $2 \%$ or less. Thus, Cholnoky's diatom analysis sheets should provide an accurate reflection of the structure of the diatom communities that he encountered. If Cholnoky's diatom community analysis is considered to be accurate then the ecological conclusions drawn from his data should be equally sound.

An explanatory note follows about working with diatom species encountered in South Africa: When diatom publications were written by various authors (Cholnoky, Giffen, Schoeman and Archibald) it was with the intention either to describe all diatom species encountered in a given sample (i.e. community structure), or to describe novel species from a particular locality. The method of illustrating these publications was with line drawings, which are both time-consuming and difficult to generate. Thus common species were usually not illustrated and the reader is most often referred to the works of Hustedt or other authors for illustrations of the species in question. Thus we have a large amount of South African literature that has few, or no, illustrations of commonly encountered diatom species, only novel and rare species. In the late 1980s workers such as Schoeman and Archibald used photographic images to illustrate articles, such as the work done in Namibia at the Gross Barmen Thermal Springs (Schoeman and Archibald, 1988). In this work common species with their variations are illustrated using photomicrograph images. 
Another obstacle encountered in relating older publications to current data and literature lies in the taxonomy and nomenclature of the diatoms. Internationally, diatom nomenclature has undergone several major upheavals and changes in the past 15 years. Since the publication of Round et al. (1990) The Diatoms: Morphology and Taxonomy of the Genera, the taxonomical trend has been to split large genera into smaller groups, establish synonyms between con-specific taxa, and to generally rearrange the diatom species into more natural groupings. In addition, many of the species described by Cholnoky have been established as synonyms for taxa described from Europe, while on the other hand many of his species have been validated and found to occur in Europe. Cholnoky also described many "African" forms of extant species, adding to taxonomical confusion. Schoeman (1973), writing after Cholnoky's death, comments: "transitional forms (of diatoms), linking certain species with their forms and varieties... clearly indicate that the demarcation into varieties or forms is often entirely superfluous and can serve no purpose at all." This comment creates doubt about the validity of Cholnoky's "African" forms.

The lack of illustration of common species together with vast changes in diatom taxonomy over the last decade has led to misconceptions about diatom taxa encountered in South Africa. The vast majority of common diatom taxa found in South Africa are cosmopolitan both in distribution (see Krammer and LangeBertalot, 1986 to 1991), and environmental tolerances. There are a number of diatom species endemic to South or Southern Africa (see Schoeman and Archibald, 1976 to 1980), but the dominant diatom species in a given community are well-known, well-documented cosmopolite species. This is illustrated in the present analysis where the majority of species occurring on Cholnoky's analysis sheets were described from Europe. Although the nomenclatural changes mentioned above can be problematic for the practical diatomist, the taxonomy and nomenclature of diatom species encountered in South Africa can be quickly updated using the wealth of modern literature and electronic databases such as OMNIDIA (Lecointe et al., 1993) - as this study demonstrates.

South Africa is in possession of an enormous database of literature, diatom material (slides and preserved material) and most importantly diatom analysis sheets currently housed in the South African Diatom Collection at the CSIR in Durban. To draw correct inferences about the water quality of a given river or stream using diatom analysis methods, several hours are needed behind a high-power microscope to determine the relative species composition of the sampled community. In addition, to evaluate the structure of a diatom community the person performing this analysis needs to have a very good knowledge of diatom taxonomy. However, the South African Diatom Collection has many original diatom analysis sheets composed from samples taken over a number of decades, commencing in the mid 1950s. These analysis sheets are available for many of South Africa's rivers. Thus when historical data is needed for a particular river system (e.g. to determine the extent of degradation over a period of time), the most time-consuming and painstaking part of using diatom indices has already been completed. It now only remains to convert these previously composed diatom analysis sheets to digital format and then generate historical ecological information based on the diatom communities using modern diatom pollution indices that have been developed and tested over several decades in Europe and elsewhere.

Diatom indices function in the following manner: In a sample from a body of water with a particular level of determinand (e.g. salinity), diatom taxa with their optimum close to that level will be most abundant. Therefore an estimate of the level of that determinand in the sample can be made from the average of the optima of all the taxa in that sample, each weighted by its abundance. This means that a taxon that is found frequently in a sample has more influence on the result than one that is rare. A further refinement is the provision of an "indicator value" which is included to give greater weight to those taxa which are good indicators of particular environmental conditions. In practice, the first step to be completed when using diatom indices is the compilation of a list of taxa in a sample, together with their absolute abundance. It is this step which has been completed for many samples by Cholnoky and his co-workers. The final index value is expressed as the mean of the optima of the taxa in the sample, weighted by the abundance of each taxon. The indicator value acts to further increase the influence of certain species (Kelly, 1998).

The diatom indices used in this analysis are known as Descy's Index or DES (Descy, 1979); the Generic Diatom Index or GDI (Coste and Ayphassorho, 1991); the Specific Pollution Sensitivity Index or SPI (Coste in CEMAGREF, 1982); the Biological Diatom Index or BDI (Lenoir and Coste, 1996); the Eutrophication/ Pollution Index or EPI (Dell'Uomo, 1996); the Artois-Picardie Diatom Index or APDI (Prygiel et al., 1996); Sládeček's Index or SLA (Sládeček, 1986); Leclercq and Maquet's Index or LMI (Leclercq and Maquet, 1987); the Commission of Economical Community Index or CEC (Descy and Coste, 1991); Schiefele and Schreiner's Index or SHE (Schiefele and Schreiner, 1991); Rott's Index or ROT (Rott, 1991); the Trophic Diatom Index or TDI (Kelly and Whitton, 1995); and the Watanabe Index or WAT (Watanabe, 1986; 1990). In all cases except in the CEC, SHE, TDI and WAT Index, the diatom indices are calculated using the formula of Zelinka and Marvan (1961). For all of the above indices, except TDI (maximum value of 100), the maximum value of 5 (converted to 20 by the software package OMNIDIA; Lecointe et al., 1993) indicates a high quality or pristine water resource.

Most of the diatom indices listed above were designed to give an indication of general water quality. The indices differ in respect to the diatom species included in the calculation and in the number of taxa included in the calculation. The first index to be developed was that of Descy. This index was followed by the SPI, which has the broadest species base of all of the indices. Several refinements followed on the SPI index that eventually culminated in the BDI, which incorporates 14 parameters of water quality. $70 \%$ of the variation in the scores of the BDI index can be explained using 14 water quality variables. The remaining $30 \%$ of the variation is ascribed to physical factors such as light penetration, current speed and general habitat integrity (Lenoir and Coste, 1996). Several indices were designed to reflect eutrophication including the EPI and the TDI. The calculation of correct scores for the TDI index is dependent on the percentage of pollution- tolerant diatom taxa in the sample $(\% \mathrm{PT})$, more than $20 \%$ PT valves indicate organic pollution rather than eutrophication. Sládeček (SLA index) and Watanabe (WAT index) developed diatom indices which were designed to reflect degrees of organic pollution.

At this point it may be useful to define the terms organic pollution and eutrophication in the context of the present paper. Organic pollution refers to unnatural addition of dissolved and particulate organic matter to an aquatic ecosystem. Organic discharges are those produced or derived from living organisms. Organic pollution of an aquatic ecosystem may result in various chemical (dissolved oxygen, nutrient levels) and physical (turbidity and suspended solids) changes that in turn drive biological changes in the receiving water body (Dallas and Day, 


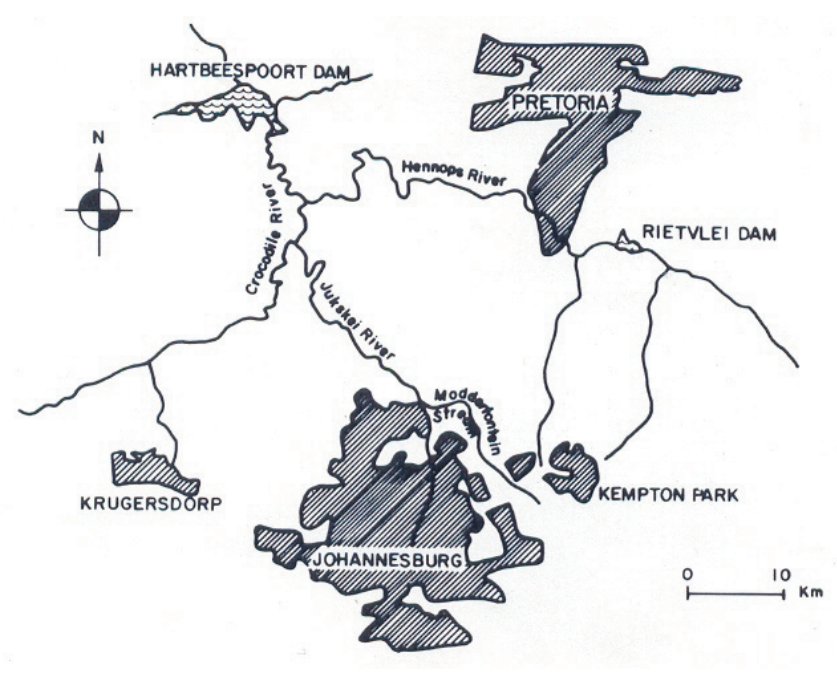

Figure 1

Location of the Jukskei-Crocodile River catchment area (Schoeman, 1982)

2004). A widely accepted definition of eutrophication is that of the Organisation for Economic cooperation and Development (OECD, 1982) which describes the process as "... the nutrient enrichment of waters which results in the stimulation of an array of symptomatic changes, amongst which is the increased production of algae and aquatic macrophytes, deterioration of water quality and other symptomatic changes that are found to be undesirable and interfere with water uses". In the classification of Nauman (1919) and Rast and Thornton (1996) the term oligotrophic means the presence of low levels of nutrients and water quality problems; mesotrophic means intermediate levels of nutrients, with emerging signs of water quality problems; and eutrophic means high levels of nutrients and an increased frequency of water quality problems.

The aim of this study is to demonstrate the value of historical diatom analysis sheets by showing that they can be used as the basis for calculating a diatom index score for a particular site. This diatom index core can in turn be useful for drawing conclusions about the past condition (up to 50 years ago) of South African rivers.

\section{Methods}

The Jukskei-Crocodile River system drains an area of $2046 \mathrm{~km}^{2}$ between Johannesburg and the Hartbeespoort Dam at an altitude of between 1200 and $1800 \mathrm{~m}$ (see Fig. 1). Climatically this region is cold and dry in winter and warm to hot in summer. About 80 to $90 \%$ of the rainfall occurs in the six summer months, i.e. between November and April (Allanson, 1961). The southern catchment area (northern Johannesburg) is densely populated and heavily industrialised, whereas the northern part consists mainly of agricultural areas. At the time of Cholnoky's work the Jukskei-Crocodile River system received effluent from many different sources including power station blow-down (mineralising effect), industrial and sewage effluent (Allanson, 1961; Schoeman, 1976). The Crocodile River drained what was then a predominantly agricultural area and accordingly contained water of a higher quality (Schoeman, 1982).

This study aims to demonstrate the usefulness of historical diatom community analysis sheets. However, several problems were encountered in using these analysis sheets. Firstly the data sheets needed to be converted to a digital format. In the present study this was achieved by entering the data first into spreadsheets and then into the OMNIDIA database. The first entry into MICROSOFT EXCEL was necessary as the data had to be electronically captured. However, if the person entering the data is proficient in the use of the OMNIDIA Database the data can be directly entered without a first, time-consuming, entry into spreadsheets. OMNIDIA (Lecointe et al., 1993) was developed for the management of diatom samples and calculation of diatom indices from abundance data generated from diatom community analysis. Data entry into OMNIDIA only requires a species acronym together with absolute abundance of the relevant diatom species. From these data the program generates the full species name and relative abundance of the species in the community, and hence is far less time-consuming than entering species data into spread- sheets. Results obtained from OMNIDIA are in the form of individual diatom analysis sheets together with site information, relative abundance of the species, population, diversity, evenness and a number of diatom index scores generated from the diatom community data (see discussion above). Alternatively diatom analysis sheets can be grouped together up to 20 at a time saving repetitive mention of species. These files can then in turn be exported to EXCEL or some other similar program.

The entry of diatom data of a historical nature using the acronym method poses several problems for the inexperienced user. The first complication that arises is whether the species name used by the original author of the analysis sheets is currently valid and recognized by the software? The validity of species names can be checked in OMNIDIA or, failing that, in a number of literature resources. If the specific or generic epithet is no longer valid then the accurate synonym can be obtained in the OMNIDIA program, or alternatively from literature resources such as Krammer and Lange-Bertalot (1986 to 1991) or Kellogg and Kellogg (2002). Secondly, the relevant acronym for data entry needs to be identified. There is a printable list of acronyms in OMNIDIA for about 9000 species, or alternatively an electronic search may be conducted by typing the full species name into OMNIDIA. The acronym construction follows certain rules and once the operator is familiar with these rules most of the acronyms can many times be determined without resorting to either a manual or electronic search.

Once the data had been entered, the database (OMNIDIA) calculated the indices listed above in the introduction. In the following section the diatom index results for this analysis will be presented and discussed.

\section{Results and discussion}

A complete species list (including synonymy) composed from the analysed data sheets is presented in Appendix 1. Species names highlighted in bold are those used in Cholnoky's original analysis sheets.

The diatom index scores generated from the diatom community analysis sheets are presented in Table 2, and should be interpreted using Table 1.

The results as presented in Table 2 can be seen to give an accurate indication of a highly impacted river system (as per Schoeman, 1976). However, caution should be exercised in interpreting the data yielded by those samples with a population lower than the 350 minimum recommended by Cholnoky in his book (Cholnoky, 1968), and later by European authors (e.g. 300 by Prygiel et al., 2002). All of the species listed on Cholnoky's diatom analysis sheets could be entered into the OMNIDIA database with the exception of Cymbella bengalensis. There is no 


\begin{tabular}{|c|c|c|}
\hline \multicolumn{3}{|c|}{$\begin{array}{c}\text { TABLE 1 } \\
\text { Class limit values for diatom indices } \\
\text { (Eloranta \& Soininen, 2002) }\end{array}$} \\
\hline Class & Trophy & Index score \\
\hline high quality & oligotrophy & $>17$ \\
\hline good quality & oligo-mesotrophy & 15 to 17 \\
\hline moderate quality & mesotrophy & 12 to 15 \\
\hline poor quality & meso-eutrophy & 9 to 12 \\
\hline bad quality & eutrophy & $<9$ \\
\hline
\end{tabular}

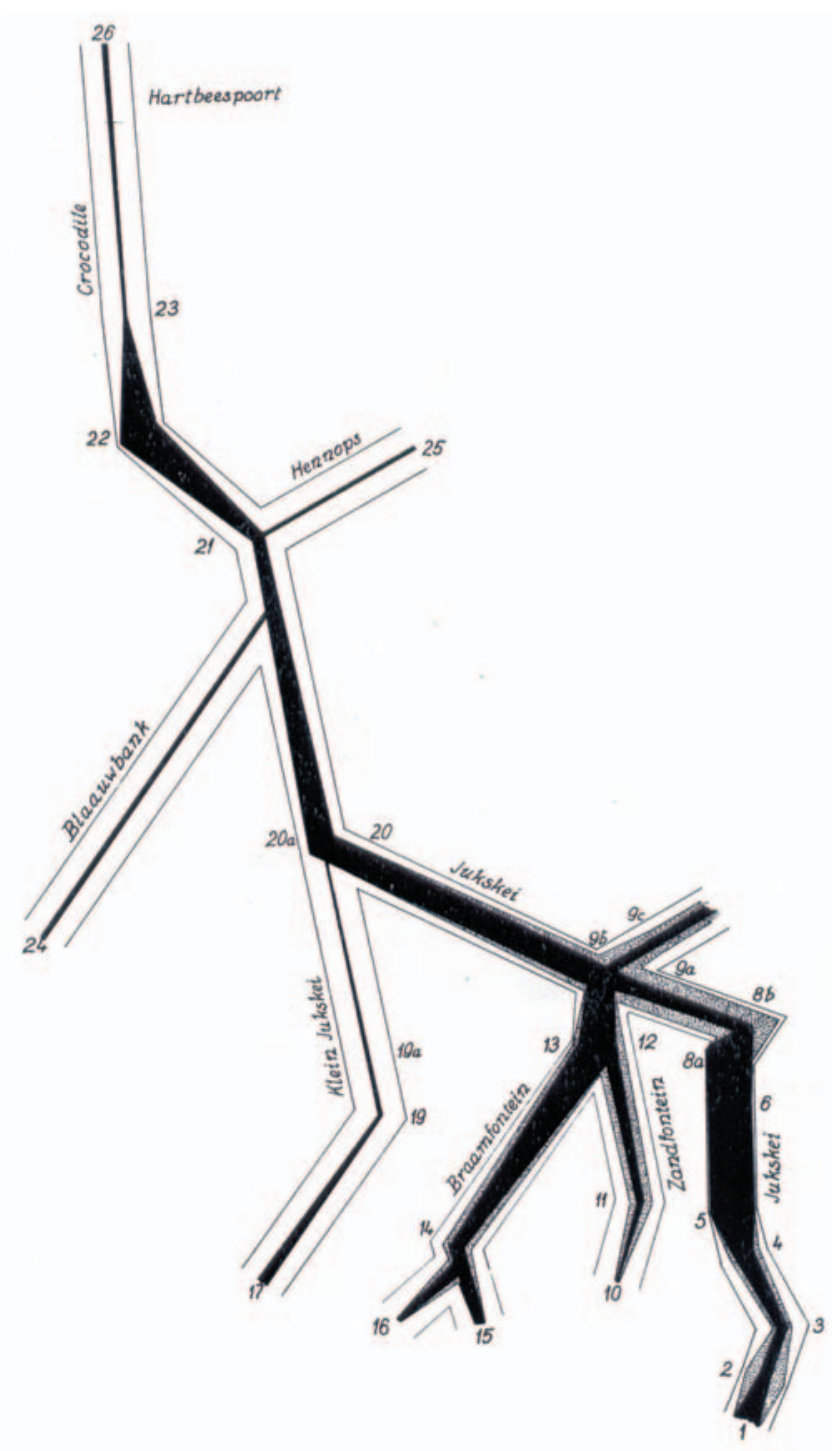

Figure 2

Abundance of the pollution tolerant diatom species Nitzschia palea (black) and Sellaphora (Navicula) seminulum (grey) in the Jukskei-Crocodile River system (Cholnoky, 1968)

acronym for this species or any of its synonyms in OMNIDIA v3.1. However, $C$. bengalensis was present in only two samples ( 5 and 7 individuals respectively), and its absence from the index calculation is not considered to exert an influence on the final score in any way. Prygiel (2003) cautions that when dominant species are not included in the index calculation then one runs the risk of incorrect assessments; however, this does not hold true for sub-dominant species.
It is interesting to compare the diatom-index data with the diagram that Cholnoky drew of the Jukskei-Crocodile River system, based on his diatom analysis at the same sampling stations he used in 1956/7 (see Fig. 2). Cholnoky constructed the diagram based on the relative abundance of two diatom species, Nitzschia palea and Sellaphora (Navicula) semminulum, both species known for their tolerance to organic pollution. It is evident from a comparison of Fig. 2 with Table 2 that the sampling stations on Cholnoky's diagram having the lowest percentage of $N$. palea and S. seminulum in the communities (hence higher quality water) have the highest scores generated from modern diatom indices. Cholnoky's diagram also agrees with the calculated percentage of pollution tolerant diatoms $(\% \mathrm{PT})$ using the TDI index of Kelly and Whitton (1995; Table 2).

It can also be deduced from Table 2 that some of the sampling stations have a diatom-index score that is representative of pristine water quality. The authors of this report consider this to be an erroneous assessment. If the samples classified as pristine (diatom index score $>17$; Table 2) are related to the abundance sheets it can be noted that all these sites have high abundance of Achnanthidium minutissimum (Achnanthes minutissima). At several of the sites with index scores indicating pristine conditions, there is a high abundance of Gomphonema parvulum. G. parvulum is known to be tolerant to several forms of pollution and indicates disturbed conditions; Cholnocky was later to add G. parvulum to his list of pollution tolerant species (Cholnoky, 1970). The occurrence of G. parvulum in a community dominated by $A$. minutissimum alerts one to the fact that there is at least moderate pollution at the site. From a re-examination of the original material it can be seen that although $A$. minutissimum composed some portion of the diatom community, the additional portion of the diatoms recorded as A. minutissimum is in fact A. saprophilum (Achnanthes minutissima var. saprophila). This species or variety cannot have been noted as separate to $A$. minitissimum in 1956 or 1957 as it was only described in 1982 (Kobayasi and Mayama, 1982) from severely polluted rivers in the vicinity of Tokyo. The valve morphology of this taxon closely resembles $A$. minutissimum. A. saprophilum has a very high tolerance to organic pollution and often occurs as the dominant taxon even in poly-saprobic water. If the TEM illustrations of A. minutissimum from Pretoria salt pan found in the work of Schoeman and Ashton (1982) are compared with those presented by Mayama and Kobayasi (1989), it can be seen that several of the photographs depicting $A$. minutissimum are undoubtedly $A$. saprophilum (see Fig. 3). The similarity in outline, pore structure and arrangement of striae should be noted in this figure.

The error of identification between the two species is very easy to remedy, in the samples where it is suspected that a portion of the count of A. minutissimum could be A. saprophilum, the original slide needs to be examined and the ratio between these two species calculated. Once the diatom analysis has been corrected in this way, the data can once more be used in accurate historical ecological assessments. It is important to do this when diatom indices are being used for assessment as the two species have different tolerance values in the diatom index equation. On re-counting the abundance of $A$. minutissimum, it was found that a percentage of the diatom valves was in fact $A$. saprophilum, the resultant relative abundance was re-calculated and when used in the diatom index calculation, lowered the index score by several points and in some cases transferred the sample to a lower water quality class (Table 1) as demonstrated in Table 3.

Of the specific indices, the EPI shows that most of the sites are eutrophic, with several falling into the meso-eutrophic class and others which could be classified as mesotrophic; no sites 
TABLE 2

Diatom index scores generated from diatom analysis sheets for the Jukskei-Crocodile River system in 1956/57 (Authored by Dr BJ Cholnoky)

\begin{tabular}{|c|c|c|c|c|c|c|c|c|c|c|c|c|c|c|c|}
\hline Sample number & $\begin{array}{l}\text { Popu- } \\
\text { lation }\end{array}$ & SPI & DES & LMI & SHE & ROT & CEC & APDI & BDI & GDI & SLA & WAT & EPI & TDI & \%PT \\
\hline JK 1 STA 8A & 565 & 1.2 & 1.1 & 5.8 & 1.3 & 6.7 & 1.6 & 6.6 & 6.7 & 1.3 & 7.7 & 1.7 & 7.5 & 75.6 & 96.5 \\
\hline JK 2 STA 8A & 604 & 1.3 & 1.2 & 5.9 & 1.6 & 5.5 & 1.8 & 6.8 & 6.5 & 1.5 & 7.9 & 2.3 & 7.0 & 75.7 & 95.2 \\
\hline JK3 STA 8A & 323 & 2.0 & 1.5 & 6.0 & 3.2 & 5.5 & 1.6 & 7.8 & 6.5 & 2.5 & 7.9 & 4.5 & 7.5 & 75.6 & 84.2 \\
\hline JK 5 STA 6 & 288 & 5.0 & 3.6 & 7.4 & 4.5 & 9.7 & 4.8 & 8.2 & 9.9 & 9.0 & 9.2 & 10.5 & 7.1 & 93.5 & 83.0 \\
\hline JK 6 STA 6 & 549 & 1.7 & 1.2 & 6.2 & 1.6 & 7.0 & 1.8 & 7.9 & 6.9 & 2.0 & 8.2 & 2.9 & 6.7 & 75.0 & 89.6 \\
\hline JK 7 STA 6 & 387 & 11.1 & 8.5 & 10.5 & 8.9 & 11.2 & 9.6 & 12.0 & 14.0 & 11.8 & 11.5 & 13.2 & 10.6 & 64.3 & 31.5 \\
\hline JK 8 STA 5 & 538 & 1.5 & 1.2 & 5.8 & 2.3 & 4.1 & 1.6 & 4.9 & 6.5 & 1.8 & 8.0 & 2.6 & 7.7 & 75.4 & 91.1 \\
\hline JK 9 STA 4 & 562 & 1.5 & 1.4 & 5.8 & 2.0 & 6.0 & 2.1 & 6.3 & 6.2 & 2.0 & 7.8 & 2.8 & 7.2 & 75.2 & 92.7 \\
\hline $\mathrm{JK} 10$ & 471 & 2.7 & 2.2 & 6.5 & 4.2 & 6.1 & 2.7 & 7.1 & 7.3 & 3.8 & 8.8 & 5.9 & 7.7 & 78.7 & 79.8 \\
\hline JK 11 & 471 & 2.1 & 1.7 & 6.0 & 3.9 & 5.1 & 2.0 & 7.5 & 6.5 & 2.7 & 8.1 & 4.9 & 7.7 & 77.4 & 83.9 \\
\hline JK 12 & 532 & 1.8 & 1.4 & 5.8 & 3.2 & 4.3 & 1.8 & 7.6 & 6.2 & 2.3 & 7.7 & 4.1 & 7.6 & 76.1 & 89.8 \\
\hline JK 13 STA 20 & 507 & 12.3 & 6.7 & 6.8 & 13.0 & 13.9 & 7.7 & 5.7 & 11.0 & 16.5 & 12.8 & 5.8 & 9.6 & 92.1 & 25.2 \\
\hline JK 14 STA 20 A & 509 & 4.3 & 3.7 & 7.6 & 6.1 & 9.6 & 6.3 & 5.4 & 11.3 & 3.8 & 10.9 & 7.9 & 8.1 & 70.2 & 56.2 \\
\hline JK 15 & 532 & 11.2 & 14.8 & 10.5 & 17.8 & 18.6 & 18.3 & 9.6 & 8.8 & 14.3 & 11.7 & 19.8 & 8.8 & 10.4 & 0.4 \\
\hline JK 16 & 528 & 12.9 & 14.5 & 10.5 & 18.1 & 18.4 & 17.2 & 9.5 & 13.9 & 14.3 & 12.1 & 19.8 & 9.8 & 9.4 & 0.2 \\
\hline JK 17 & 562 & 16.9 & 15.4 & 14.0 & 18.1 & 18.0 & 18.3 & 10.4 & 14.6 & 18.4 & 15.3 & 18.8 & 12.6 & 5.0 & 2.0 \\
\hline JK 18 & 523 & 11.4 & 13.5 & 10.6 & 16.5 & 16.8 & 16.8 & 9.6 & 9.3 & 14.2 & 11.8 & 19.6 & 9.1 & 26.4 & 0.8 \\
\hline JK 19 & 533 & 11.8 & 13.7 & 10.5 & 18.4 & 18.9 & 17.2 & 9.5 & 10.3 & 14.4 & 11.9 & 19.6 & 9.1 & 12.1 & 1.3 \\
\hline JK 101 STA 1 & 265 & 4.9 & 5.7 & 8.3 & 8.0 & 11.9 & 6.1 & 9.4 & 11.6 & 3.1 & 10.9 & 10.5 & 12.0 & 77.2 & 54.7 \\
\hline JK 102 STA 2 & 282 & 2.9 & 4.9 & 6.4 & 4.8 & 6.6 & 5.2 & 2.2 & 10.1 & 7.9 & 12.5 & 4.6 & 11.7 & 94.4 & 50.0 \\
\hline JK 103 STA 3 & 247 & 6.8 & 9.9 & 7.2 & 5.4 & 7.8 & 5.9 & 5.4 & 10.9 & 9.2 & 9.3 & 8.9 & 10.6 & 93.3 & 62.3 \\
\hline JK 103B STA 3 & 268 & 5.1 & 7.1 & 8.1 & 6.4 & 8.8 & 4.2 & 5.2 & 9.7 & 7.8 & 12.1 & 9.2 & 8.8 & 87.5 & 48.1 \\
\hline JK 104 STA 4 & 325 & 2.9 & 4.0 & 6.5 & 4.2 & 7.4 & 3.9 & 4.8 & 7.9 & 6.9 & 10.4 & 8.1 & 8.8 & 90.9 & 79.7 \\
\hline JK 105 STA 5 & 349 & 5.7 & 6.2 & 6.2 & 5.4 & 5.7 & 4.4 & 5.4 & 9.7 & 11.5 & 8.2 & 10.7 & 9.2 & 95.1 & 88.0 \\
\hline JK 106 STA 8A & 347 & 6.4 & 9.1 & 8.9 & 10.8 & 8.9 & 4.2 & 8.6 & 8.7 & 10.4 & 12.9 & 11.5 & 8.0 & 83.2 & 46.4 \\
\hline JK 106B STA 8B & 258 & 4.5 & 6.7 & 6.7 & 7.7 & 9.5 & 4.2 & 7.5 & 9.3 & 6.5 & 12.0 & 10.8 & 9.9 & 85.1 & 65.1 \\
\hline JK 107A STA 9A & 318 & 4.1 & 5.5 & 6.0 & 2.9 & 8.4 & 4.8 & 5.0 & 9.1 & 9.3 & 10.9 & 14.0 & 9.5 & 97.5 & 78.6 \\
\hline JK 107B STA 9B & 265 & 4.0 & 7.0 & 7.6 & 7.3 & 9.3 & 5.2 & 6.6 & 9.3 & 9.5 & 11.4 & 9.8 & 8.9 & 93.4 & 70.2 \\
\hline JK 107C STA 9C & 287 & 5.0 & 8.2 & 8.0 & 7.0 & 9.2 & 5.4 & 5.5 & 10.4 & 8.0 & 12.1 & 8.8 & 9.2 & 90.0 & 36.6 \\
\hline JK 108 STA 10 & 301 & 18.5 & 14.3 & 14.3 & 15.3 & 15.2 & 18.7 & 5.8 & 17.0 & 13.4 & 14.7 & 20.0 & 12.5 & 100.0 & 10.3 \\
\hline JK 109A STA 11 & 349 & 4.7 & 4.5 & 7.6 & 6.4 & 7.1 & 3.3 & 2.3 & 7.3 & 8.9 & 10.2 & 11.0 & 8.3 & 95.5 & 25.5 \\
\hline JK 109B STA 11 & 338 & 3.9 & 4.7 & 6.7 & 5.1 & 6.8 & 4.6 & 4.8 & 8.0 & 8.5 & 9.8 & 10.5 & 9.2 & 94.7 & 64.2 \\
\hline JK 109C STA 11 & 313 & 4.2 & 5.8 & 7.3 & 6.4 & 6.7 & 3.7 & 2.6 & 7.5 & 9.1 & 10.2 & 10.3 & 9.1 & 95.3 & 26.2 \\
\hline JK 110A STA 12 & 157 & 6.1 & 6.8 & 8.5 & 8.6 & 9.9 & 5.8 & 7.7 & 9.6 & 9.8 & 11.1 & 9.6 & 9.5 & 87.7 & 55.4 \\
\hline JK 110B STA 12 & 310 & 12.9 & 14.7 & 14.6 & 13.4 & 14.0 & 12.0 & 14.2 & 12.3 & 12.2 & 14.5 & 11.0 & 8.8 & 55.2 & 6.8 \\
\hline JK 111 STA 13 & 299 & 2.6 & 3.2 & 6.3 & 3.2 & 11.3 & 4.4 & 8.1 & 8.5 & 3.3 & 9.6 & 6.2 & 10.7 & 82.4 & 81.6 \\
\hline JK 112 STA 14 & 272 & 4.0 & 6.2 & 6.6 & 5.8 & 7.7 & 7.1 & 5.6 & 10.1 & 8.4 & 10.1 & 9.7 & 10.3 & 93.8 & 72.8 \\
\hline JK 113 STA 15 & 351 & 12.0 & 10.6 & 12.1 & 13.7 & 15.2 & 16.2 & 8.9 & 16.1 & 1.8 & 13.7 & 16.4 & 12.8 & 78.7 & 20.2 \\
\hline JK 114 STA 16 & 263 & 10.4 & 11.8 & 11.1 & 11.5 & 11.7 & 11.1 & 7.8 & 12.8 & 9.8 & 12.3 & 16.4 & 10.3 & 87.5 & 31.2 \\
\hline JK 115 STA 20 & 262 & 3.8 & 4.8 & 7.3 & 5.4 & 8.6 & 3.5 & 4.6 & 7.9 & 8.8 & 12.3 & 8.1 & 9.1 & 91.7 & 87.4 \\
\hline JK 116 STA 20A & 259 & 1.5 & 2.2 & 5.9 & 2.3 & 5.5 & 3.9 & 4.1 & 8.0 & 9.6 & 10.3 & 2.7 & 9.2 & 95.1 & 94.6 \\
\hline JK 117 STA 21 & 234 & 7.0 & 7.3 & 8.2 & 9.6 & 12.5 & 7.1 & 7.9 & 10.6 & 9.5 & 11.8 & 10.8 & 11.2 & 75.3 & 43.6 \\
\hline JK 119 STA 8B & 347 & 3.3 & 2.9 & 6.7 & 4.5 & 5.5 & 2.9 & 1.8 & 10.7 & 7.5 & 12.9 & 2.4 & 8.0 & 93.6 & 24.2 \\
\hline JK 120 STA 10 & 345 & 18.4 & 14.3 & 14.4 & 15.6 & 15.2 & 13.5 & 5.8 & 17.3 & 10.8 & 14.8 & 19.8 & 12.6 & 98.3 & 8.1 \\
\hline JK 122 STA 9A & 267 & 2.8 & 2.1 & 6.0 & 2.9 & 5.2 & 4.6 & 1.7 & 9.7 & 7.2 & 12.5 & 3.9 & 9.3 & 92.7 & 43.4 \\
\hline JK 123 STA 17 & 297 & 14.0 & 13.5 & 12.3 & 14.9 & 15.3 & 16.2 & 12.4 & 13.3 & 8.6 & 13.8 & 15.7 & 11.6 & 46.6 & 6.1 \\
\hline JK 124 STA 19A & 367 & 17.5 & 15.9 & 14.0 & 15.9 & 16.2 & 17.3 & 7.6 & 16.8 & 13.7 & 14.6 & 18.8 & 12.2 & 45.4 & 6.3 \\
\hline JK 125 STA 20 & 309 & 10.3 & 14.0 & 10.1 & 14.3 & 11.8 & 11.5 & 7.2 & 13.0 & 11.4 & 10.7 & 12.3 & 8.1 & 64.2 & 13.6 \\
\hline JK 126 STA 2 & 280 & 6.1 & 7.0 & 6.5 & 3.2 & 6.8 & 5.9 & 4.6 & 9.5 & 12.3 & 11.3 & 16.1 & 9.5 & 98.7 & 70.0 \\
\hline JK 127 STA 3 & 313 & 4.2 & 2.6 & 7.2 & 3.9 & 9.6 & 4.4 & 9.4 & 9.5 & 6.9 & 8.4 & 7.9 & 7.1 & 89.6 & 87.5 \\
\hline JK 128 STA 4 & 164 & 6.7 & 9.4 & 8.4 & 9.6 & 8.1 & 6.3 & 5.9 & 9.7 & 7.0 & 10.3 & 12.9 & 8.0 & 95.1 & 48.2 \\
\hline JK 129 STA 5 & 281 & 1.6 & 1.5 & 6.1 & 2.3 & 7.9 & 3.5 & 8.8 & 7.3 & 2.6 & 8.0 & 3.3 & 7.3 & 79.4 & 93.6 \\
\hline JK 130 STA 6 & 347 & 4.4 & 2.9 & 6.7 & 9.2 & 9.0 & 1.8 & 5.9 & 6.9 & 2.0 & 8.5 & 7.9 & 7.0 & 80.1 & 36.6 \\
\hline JK 131 STA 8B & 347 & 3.2 & 2.9 & 6.5 & 4.5 & 7.5 & 3.9 & 7.4 & 7.8 & 5.5 & 8.5 & 7.8 & 8.0 & 87.1 & 82.1 \\
\hline JK 132 STA 12 & 301 & 6.0 & 13.1 & 8.9 & 12.7 & 10.5 & 4.4 & 5.9 & 7.2 & 2.1 & 9.3 & 10.6 & 6.8 & 85.7 & 17.3 \\
\hline
\end{tabular}




\begin{tabular}{|c|c|c|c|c|c|c|c|c|c|c|c|c|c|c|c|}
\hline \multicolumn{16}{|c|}{ TABLE 2 (continued) } \\
\hline Sample number & $\begin{array}{l}\text { Popu- } \\
\text { lation }\end{array}$ & SPI & DES & LMI & SHE & ROT & CEC & APDI & BDI & GDI & SLA & WAT & EPI & TDI & \%PT \\
\hline JK 133 STA 16 & 308 & 10.8 & 13.5 & 10.9 & 11.8 & 12.8 & 11.1 & 8.9 & 10.7 & 9.3 & 12.3 & 13.7 & 8.9 & 63.7 & 18.5 \\
\hline JK 134 STA 17 & 313 & 15.1 & 14.1 & 10.9 & 16.2 & 14.2 & 14.9 & 11.3 & 13.1 & 14.3 & 12.0 & 16.8 & 10.8 & 59.5 & 3.5 \\
\hline JK 135 STA 19 & 375 & 15.3 & 14.0 & 12.3 & 15.3 & 17.0 & 16.4 & 11.5 & 15.0 & 15.2 & 14.7 & 17.8 & 12.6 & 45.0 & 5.3 \\
\hline JK 136 STA 20A & 300 & 2.0 & 2.0 & 6.2 & 1.6 & 7.0 & 3.5 & 6.3 & 6.2 & 4.1 & 8.3 & 6.8 & 7.7 & 85.6 & 92.3 \\
\hline JK 137 STA 21 & 423 & 17.6 & 15.0 & 14.7 & 17.5 & 16.9 & 17.7 & 8.0 & 16.1 & 16.8 & 15.3 & 18.9 & 12.7 & 9.9 & 0.5 \\
\hline JK 138 STA 22 & 344 & 3.3 & 2.0 & 6.7 & 4.5 & 7.0 & 4.6 & 6.1 & 5.7 & 3.7 & 8.0 & 6.2 & 7.6 & 75.4 & 89.0 \\
\hline JK 139 STA 23 & 351 & 12.3 & 14.4 & 12.3 & 11.8 & 10.2 & 12.4 & 7.1 & 14.2 & 11.0 & 11.4 & 15.6 & 10.7 & 82.4 & 2.8 \\
\hline JK 140 STA 24 & 338 & 14.5 & 14.4 & 13.0 & 15.3 & 15.4 & 15.6 & 12.9 & 14.3 & 12.4 & 13.6 & 16.5 & 11.9 & 55.8 & 7.1 \\
\hline JK 141 STA 24 & 328 & 16.3 & 13.7 & 12.5 & 15.9 & 15.7 & 17.0 & 13.9 & 15.5 & 15.1 & 13.8 & 16.6 & 11.5 & 43.2 & 3.4 \\
\hline JK 142 STA 26(1) & 431 & 13.3 & 13.3 & 12.0 & 14.0 & 13.4 & 14.3 & 12.2 & 16.5 & 11.4 & 12.6 & 16.1 & 11.6 & 62.2 & 9.5 \\
\hline JK 143 STA 26(2) & 363 & 16.0 & 17.5 & 13.5 & 18.4 & 13.2 & 17.0 & 14.4 & 15.4 & 12.3 & 14.1 & 7.9 & 12.5 & 89.5 & 0.3 \\
\hline JK 144 STA 26 (3) & 407 & 14.6 & 15.1 & 12.9 & 14.3 & 13.1 & 14.3 & 11.5 & 16.3 & 12.7 & 13.1 & 17.8 & 12.1 & 54.6 & 4.4 \\
\hline JK 145 STA 1 & 341 & 15.3 & 12.7 & 13.3 & 15.3 & 15.0 & 18.1 & 5.8 & 16.9 & 15.8 & 14.2 & 17.9 & 12.9 & 77.7 & 10.9 \\
\hline JK 146 STA 2 & 404 & 3.2 & 2.7 & 5.9 & 3.2 & 5.0 & 5.0 & 1.7 & 10.4 & 8.7 & 12.6 & 4.2 & 9.4 & 96.7 & 35.4 \\
\hline JK 147 STA 3 & 300 & 3.3 & 3.1 & 6.4 & 4.5 & 6.3 & 3.7 & 4.3 & 8.1 & 5.8 & 9.3 & 6.6 & 7.0 & 89.3 & 67.0 \\
\hline JK 148 STA 4 & 163 & 4.4 & 4.6 & 7.1 & 6.1 & 8.6 & 5.0 & 5.6 & 8.3 & 6.3 & 10.2 & 9.3 & 9.6 & 90.1 & 61.3 \\
\hline JK 149 STA 5 & 204 & 3.4 & 3.2 & 6.5 & 5.4 & 6.2 & 3.5 & 7.5 & 7.4 & 5.0 & 8.5 & 7.5 & 8.0 & 82.7 & 71.6 \\
\hline JK 150 STA 6 & 361 & 7.0 & 3.5 & 8.1 & 6.7 & 9.2 & 4.2 & 9.5 & 10.8 & 11.3 & 11.2 & 10.5 & 6.6 & 89.6 & 59.6 \\
\hline JK 151 STA 8B & 259 & 3.4 & 2.8 & 6.6 & 5.1 & 6.3 & 2.9 & 6.4 & 7.3 & 4.5 & 9.1 & 6.5 & 7.3 & 80.2 & 71.0 \\
\hline JK 152 STA 9A & 623 & 1.2 & 1.0 & 5.8 & 1.3 & 4.8 & 1.6 & 1.8 & 7.0 & 1.7 & 8.6 & 1.3 & 8.3 & 77.7 & 91.3 \\
\hline JK 153 STA 9B & 424 & 2.3 & 1.7 & 6.0 & 2.9 & 5.3 & 3.3 & 2.3 & 8.2 & 5.1 & 10.8 & 4.1 & 8.9 & 87.7 & 67.9 \\
\hline \multicolumn{16}{|c|}{$\begin{array}{l}\text { SPI; Specific Pollution Sensitivity Index, DES; Descy’s Index, LMI; Leclercq \& Maquet’s Index, SHE; Schiefele and Schreiner's Index, ROT; } \\
\text { Rott's Index, CEC; Council for European Communities Index, APDI; Artois-Picardie Diatom Index, BDI; Biological Diatom Index, GDI; Ge- } \\
\text { neric Diatom Index, SLA; Sládeček's Index, WAT; Watanabe's Index, EPI; Eutrophication/Pollution Index, TDI; Trophic Diatom Index, \%PT; } \\
\text { Percenage Pollution Tolerant Species }\end{array}$} \\
\hline
\end{tabular}

\begin{tabular}{|c|c|c|c|c|c|}
\hline \multicolumn{6}{|c|}{$\begin{array}{c}\text { TABLE } 3 \\
\begin{array}{c}\text { Diatom index scores before and after reclassification of Achnan- } \\
\text { thidium minutissimum and } A \text {. saprophilum }\end{array}\end{array}$} \\
\hline & \multicolumn{5}{|c|}{$\begin{array}{c}\text { Index score with all species as } \\
\text { A. minutissimum }\end{array}$} \\
\hline Site & SPI & SHE & BDI & WAT & ROT \\
\hline JK 141 STA 24 & 16.3 & 15.9 & 15.5 & 16.6 & 15.7 \\
\hline JK 143 STA 26 (2) & 16 & 18.4 & 15.4 & 7.9 & 13.2 \\
\hline \multirow[t]{2}{*}{ JK 144 STA 26 (3) } & 14.6 & 14.3 & 16.3 & 17.8 & 13.1 \\
\hline & \multicolumn{5}{|c|}{$\begin{array}{l}\text { Index score after splitting of } \\
\text { A. minutissimum and } A \text {. saprophilum }\end{array}$} \\
\hline JK 141 STA 24 & 15.5 & 13.7 & 13.4 & 14.2 & 13.4 \\
\hline JK 143 STA 26 (2) & 14.9 & 16.8 & 12 & 5.8 & 9.3 \\
\hline JK 144 STA 26 (3) & 13.6 & 12.4 & 14.9 & 15.6 & 11.3 \\
\hline \multicolumn{6}{|c|}{$\begin{array}{l}\text { SPI; Specific Pollution Sensitivity Index, SHE; Schiefele and Schreiner's } \\
\text { Index, BDI; Biological Diatom Index, WAT; Watanabe's Index, ROT; Rott's } \\
\text { Index }\end{array}$} \\
\hline
\end{tabular}

subject (as it still is) to high loading with organic pollutants. The GDI has a lower resolution being based only on the genus of the taxa composing the diatom communities. Although far simpler to use than indices that rely on species level identification it seems to yield comparable results in most cases.

The diatom index scores were correlated to the average water quality variables at 10 of the sites for which average annual data were available and the results are presented in Table 4.

It is interesting to note that the strongest correlations are between nitrogen and the diatom index scores, with no significant correlation to either orthophosphate-phosphorus or to total phosphate. This would suggest that the major impact in the system is from waste containing nitrogenous compounds. This finding is in agreement with Cholnoky's assessment at the time, showing that at some sites almost all of the diatom species encountered were tolerant to organic pollution, which in turn may result in nutrient enrichment

warrant the classification of oligotrophic. The TDI is included for the \% $\% \mathrm{PT}$ valves as the index itself was developed for monitoring sewage outfall (orthophosphate-phosphorus concentrations) and not organic pollution or general stream quality (Kelly and Whitton, 1995). The index cannot be used accurately if the $\% \mathrm{PT}$ valves are above 20 . The $\% \mathrm{PT}$ valves do however, demonstrate that for the most part the Jukskei-Crokodile system was
(Dallas and Day, 2004). Other strong correlations exist between the diatom index scores and electrical conductivity and the major ions. This correlation between ionic compounds matches a descriptive assessment of the Jukskei-Crocodile system as being heavily impacted by industrial and agricultural runoff and effluents. 


\begin{tabular}{|c|c|c|c|c|c|c|c|c|c|c|c|c|}
\hline \multicolumn{13}{|c|}{$\begin{array}{c}\text { TABLE } 4 \\
\begin{array}{c}\text { Correlation between water quality variables at selected sites in the Jukskei-Crocodile system and } \\
\text { diatom index scores generated from re-analysis of historical data sheets } \\
\text { Marked correlations are significant at } p<0.05 \\
n=10 \text { (Casewise deletion of missing data) }\end{array}\end{array}$} \\
\hline & SPI & DES & LMI & SHE & ROT & CEC & APDI & BDI & GDI & SLA & WAT & EPI \\
\hline $\mathrm{pH}$ & 0.67 & 0.64 & 0.77 &.. & 0.64 & 0.74 &.. & 0.81 & .. & 0.64 & 0.77 & 0.77 \\
\hline $\mathrm{EC}$ &.. & -0.68 &.. & .. & -0.67 & .. & -0.86 & .. & -0.81 &.. & .. &.. \\
\hline Temp. & 0.68 & 0.64 & 0.69 & .. & 0.73 & 0.76 &.. & 0.72 & 0.35 & 0.86 & 0.69 & 0.81 \\
\hline COD &.. &.. &.. &.. &.. &.. & -0.89 &.. & -0.65 &.. &.. &.. \\
\hline $\mathrm{NH}_{4}-\mathrm{N}$ & -0.85 & -0.86 & -0.86 & -0.79 & -0.84 & -0.82 & -0.78 & -0.85 &.. & -0.69 & -0.86 & -0.76 \\
\hline $\mathrm{NO}_{2}-\mathrm{N}$ & -0.78 & -0.82 & -0.76 & -0.74 & -0.79 & -0.74 & -0.85 & -0.74 &.. &.. & -0.77 & -0.64 \\
\hline $\mathrm{NO}_{3}-\mathrm{N}$ &.. &.. &.. &.. &.. &.. & -0.76 &.. & -0.73 &.. &.. &.. \\
\hline KJ-N & -0.82 & -0.85 & -0.82 & -0.79 & -0.83 & -0.78 & -0.87 & -0.78 &.. & -0.65 & -0.82 & -0.68 \\
\hline $\mathrm{PO}_{4}-\mathrm{P}$ &.. &.. & .. & .. & .. &.. &.. &.. & .. & .. &.. &.. \\
\hline Total P &.. &.. &.. &.. &.. &.. &.. &.. &.. &.. &.. &.. \\
\hline $\mathrm{Na}^{+}$ &.. & -0.65 &.. & .. & -0.64 & .. & -0.87 &.. & -0.76 & .. & .. & .. \\
\hline $\mathrm{K}^{+}$ &.. &.. &.. &.. &.. &.. &.. &.. & -0.75 &.. &.. &.. \\
\hline $\mathrm{Ca}^{2+}$ & .. &.. &.. &.. &.. & .. & -0.80 &.. & -0.86 & .. & .. &.. \\
\hline $\mathrm{Mg}^{2+}$ & -0.74 & -0.75 & -0.66 & -0.74 & -0.79 & -0.70 & .. & -0.67 & .. & -0.69 & -0.68 & .. \\
\hline $\mathrm{SO}^{4-}$ & -0.77 & -0.80 & -0.73 & -0.74 & -0.80 & -0.73 & -0.90 & -0.68 & -0.71 & -0.66 & -0.74 &.. \\
\hline $\mathrm{Cl}^{-}$ & -0.69 & -0.73 & -0.66 & -0.67 & -0.73 & -0.66 & -0.90 &.. & -0.74 &.. & -0.67 &.. \\
\hline \multicolumn{13}{|c|}{ Variables were measured in mg. $\ell^{-1}$ except for temperature $\left({ }^{\circ} \mathrm{C}\right)$, electrical conductivity $\left(\mu \mathrm{S} . \mathrm{cm}^{-1}\right)$} \\
\hline \multicolumn{13}{|c|}{$\begin{array}{l}\text { SPI; Specific Pollution Sensitivity Index, DES; Descy’s Index, LMI; Leclercq \& Maquet’s Index, SHE; Schiefele and } \\
\text { Schreiner's Index, ROT; Rott's Index, APDI; Artois-Picardie Diatom Index, CEC; Council for European Communi- } \\
\text { ties Index, BDI; Biological Diatom Index, GDI; Generic Diatom Index, SLA; Sládeček’s Index, WAT; Watanabe's } \\
\text { Index, EPI; Eutrophication/Pollution Index }\end{array}$} \\
\hline
\end{tabular}

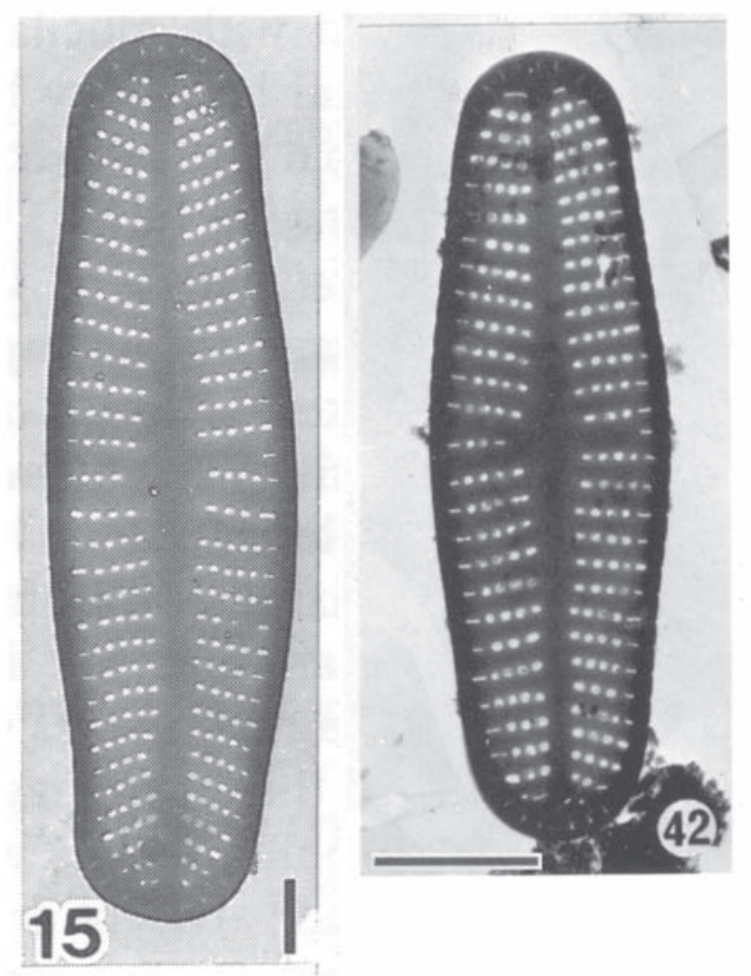

Figure 3

15; Achnanthidium saprophilum (Mayama and Kobayasi, 1989), scale bar $=1 \mu \mathrm{m}$. 42; Achnanthidium minutissimum (Schoeman and Ashton, 1982), scale bar $=2 \mu \mathrm{m}$

\section{Conclusions}

In general it can be concluded from the preceding sections that the diatom analysis sheets authored by Dr Cholnoky constitute a valuable resource from which accurate inferences may be drawn concerning the past ecological status of the rivers and streams for which data exist in the SA Diatom Collection dating from the mid 1950s. The classification of the various sampling stations carried out by Cholnoky yields similar results to those gained by using modern diatom indices. The use of diatom indices relies on information stored in a database rather than the operator's own knowledge, and thus provides a relatively rapid and more efficient assessment technique when compared to those employed by Cholnoky half a century ago.

The diatom analysis sheets contained in the SA Diatom Collection are likely to prove to be a valuable resource for obtaining historical data against which present-day and/or future environmental assessments may be compared, and provide a measure of either degradation of restoration since the time of original sampling. OMNIDIA proves to be both useful as a database and as a tool for calculating diatom index scores.

It has been demonstrated that the species listed on the diatom analysis sheets can be related to current nomenclature (synonyms; see Appendix 1) when necessary, and entered into the electronic database OMNIDIA. The diatom analysis sheets provide enough data for the calculation of accurate diatom index scores. Results generated from diatom analysis sheets with a population count of less than 300 should be regarded with caution. 
Besides the difficulties encountered caused by the identification of Achnanthidium minutissimum, the historical species data sheets contained in the SA Diatom Collection are of a quality sufficient to allow for the generation of accurate, high-confidence results that support the formulation of ecologically-based inferences on past ecosystem condition.

\section{References}

ALLANSON BR (1961) Investigations into the ecology of polluted inland waters in the Transvaal. Hydrobiol. 18 1-76.

CHOLNOKY BJ (1958) Die Diatomeenassoziation des Sumpfes Olifantsvlei südwestlich Johannesburg. Ber. Dtsch. Bot. Ges. 71 177187.

CHOLNOKY BJ (1968) Die Ökologie der Diatomeen in Binnengewässern. J Cramer, Lehre.

CHOLNOKY BJ (1970) Bacillariophyceae from the Bangweulu Swamps. Cercle Hydrobiologique de Bruxelles, Brussels.

CEMAGREF (1982) Etude des méthodes biologiques quantitatives d'appréciation de la qualité des eaux. Rapport Division Qualité des Eaux Lyon - Agence Financière de Bassin Rhône- MéditerranéeCorse. Pierre-Bénite.

COSTE M and AYPHASSORHO (1991) Étude de la qualité des eaux du Bassin Artois-Picardie à l'aide des communautés de diatomées benthiques (application des indices diatomiques). Rapport CEMAGREF. Bordeaux - Agence de l'Eau Artois-Picardie, Douai.

DALLAS HF and DAY JA (2004) The Effect of Water Quality Variables on Riverine Ecosystems: A Review. WRC Report No TT 224/04. Water Research Commission, Pretoria.

DELL'UOMO A (1996) Assessment of water quality of an Apennine river as a pilot study. In: WHITTON BA and ROTT ? initials(eds.) Use of Algae for Monitoring Rivers II. Institut für Botanik. Universität Innsbruck. pp 65-73.

DESCY J-P (1979) A new approach to water quality estimation using diatoms. Nova Hedwigia 64 305-323.

DESCY J-P and COSTE M (1991) A test of methods for assessing water quality based on diatoms. Verh. Int. Verein. Limnol. 24 2112-2116.

ELORANTA P and SOININEN J (2002) Ecological status of Finnish rivers evaluated using benthic diatom communities. J. Appl. Phycol. 14 1-7.

KELLOGG B and KELLOGG DE (2002) Diatom Monographs. Vol. 1. Non-Marine and Littoral Diatoms from Antarctic and Subantarctic regions: Distribution and Updated Taxonomy. ARG Gantner Varlag Kommanditgesellschaft, Ruggell.

KELLY MG (1998) Use of community-based indices to monitor eutrophication in European rivers. Environ. Conserv. 25 22-29.

KELLY MG and WHITTON BA (1995) The trophic diatom index: a new index for monitoring eutrophication in rivers. J. Appl. Phycol. $7433-444$

KOBAYASI H and MAYAMA S (1982) Most pollution tolerant diatoms of severely polluted rivers in the vicinity of Tokyo. Jap. J. Phycol. 30 188-196.

KRAMMER K and LANGE-BERTALOT H (1986-1991) Bacillariophyceae. 1-4. In: Ettl H, Gerloff J, Heynig H and Mollenhauer D (eds.) Süßwasserflora von Mitteleuropa Band 2. Spektrum Akademischer Verlag, Heidelberg, Berlin.

LANGE-BERTALOT H (1978) Diatomeen-Differentialarten anstelle von Leitformen ein geeigneteres Kriterium der Gewässerbelastung. Arch. Hydrobiol. Suppl. 51 393-427.

LECLERQ L and MAQUET B (1987) Deux nouveaux indices chimique et diatomique de qualité d'eau courante. Application au Samson et à ses affluents (bassin de la Meuse belge). Comparaison avec d'autres indices chimiques, biocénotiques et diatomiques. Institut Royal des Sciences Naturelles de Belgique, document de travail 28

LECOINTE C, COSTE M and PRYGIEL J (1993) "Omnidia": Software for taxonomy, calculation of diatom indices and inventories management. Hydrobiol. 269/270 509-513.

LENOIR A and COSTE M (1996) Development of a practical diatom index of overall water quality applicable to the French National Water Board network. In: WHITTON BA and ROTT E (eds.) Use of Algae for Monitoring Rivers II. Institut für Botanik. Universität Innsbruck. pp 29-43.

MAYAMA S and KOBAYASI H (1989) Sequential valve developmen in the monoraphid diatom Achnanthes minutissima var. saprophila. Diatom Res. 4(1) 111-117.

NAUMAN (1919) Nagra synpunkter angalnde limnoplanktons okologie, med sarskild hansyn till fytoplankton. Svensk Bot. Tidskr. 13 129-163.

OECD (ORGANISATION FOR ECONOMIC CO-OPERATION AND DEVELOPMENT) (1982) Eutrophication of waters: Monitoring, assessment and Control. Technical Report. OECD, Paris.

PRYGIEL J (2003) Personal communication. Mission Ecologie du Milieu, Agence de l'Eau Artois-Picardie. 200, rue Marceline, 59508 Douai Cedex, France.

PRYGIEL J, CARPENTIER P, ALMEIDA S, COSTE M, DRUART J-C, ECTOR L, GUILLARD D, HONERÉ MA, ISERENTANT R, LEDEGANCK P, LALANNE-CASSOU C, LESNIAK C, MERCIER I, MONCAUT P, NAZART M, NOUCHET N, PERES F, PEETERS V, RIMET F, RUMEAU A, SABATER S, STRAUB F, TORRISI M, TUDESQUE L, VAN DER VIJVER B, VIDAL H, VIZINET J, and ZYDEK N (2002) Determination of the biological diatom index (IBD NF T 90-354): Results of an intercomparison exercise. J. Appl. Phycol. 14 27-39.

PRYGIEL J, LÉVÊQUE L and ISERENTANT R (1996) Un nouvel indice diatomique pratique pour l'évaluation de la qualité des eaux en réseau de surveillance. Rev. Sci. Eau 1 97-113.

RAST W and THORNTON JA (1996) Trends in eutrophication research and control. Hydrol.Proc. 10 295-313.

ROTT E (1991) Methodological aspects and perspectives in the use of periphyton for monitoring and protecting rivers. In: WITTON BA, ROTT E and G. FRIEDRICH (eds.) Use of Algae for Monitoring Rivers. Institut fur Botanik, Univ. Innsbruck: 9-16.

ROUND FE, CRAWFORD RM and MANN DG (1990) The Diatoms: Biology and Morphology of the Genera. Cambridge University Press, Cambridge.

SCHIEFELE S and SCHREINER C (1991) The use of diatoms for monitoring nutrient enrichment, acidification and impact of salt in rivers in Germany and Austria. In: WITTON BA, ROTT E and G. FRIEDRICH (eds.) Use of Algae for Monitoring Rivers. Institut fur Botanik, Univ. Innsbruck: 103-110.

SCHOEMAN FR (1973) A Systematical and Ecological Study of the Diatom Flora of Lesotho with Special Reference to the Water Quality. V\&R Printers, Pretoria.

SCHOEMAN FR (1976) Diatom indicator groups in the assessment of water quality in the Jukskei-Crocodile River system (Transvaal, Republic of South Africa). J. Limnol. Soc. S. Afr. 2 (1) 21-24.

SCHOEMAN FR (1982) The diatoms of the Jukskei-Crocodile River system (Transvaal, Republic of South Africa): A preliminary checklist. J. S. Afr. Bot 48 (3) 295-310.

SCHOEMAN FR and ARCHIBALD REM (1976-1980) The Diatom Flora of Southern Africa. National Institute for Water Research, Pretoria.

SCHOEMAN FR and ARCHIBALD REM (1988) Taxonomic notes on the diatom (Bacillariophyceae) of the Gross Barmen thermal springs in South West Africa/Namibia. S. Afr. J. Bot. 54 (3) 221-256.

SCHOEMAN FR and ASHTON PJ (1982) The diatom flora in the vicinity of the Pretoria salt pan Transvaal, Republic of South Africa I. Nova Hedwigia 72 21- 54.

SLÀDEČEK V (1986) Diatoms as indicators of organic pollution. Acta Hydrochim. Hydrobiol. 14(5) 555-566.

TER BRAAK CJF and PRENTICE IC (1988) A theory of gradient analysis. Adv. Ecol. Res. 18 93-138.

WATANABE T (1982) Numerical Assessment of River Pollution Based on the Water Quality Chart. Research Report on Environmental Science. No B121-R-12-10 pp 92-95 (in Japanese).

WATANABE T (1990) Numerical simulation of organic pollution in flowing waters. In: Encyclopaedia of Environmental Control Technology. Vol 4: Hazardous Waste Containment and Treatment. Gulf Publishing Company, Houston, Texas. pp 251-281.

ZELINKA M and MARVAN P (1961) Zur Präzisierung der biologischen Klassifikation der Reinheit fliessender Gewässer. Archiv Hydrobiol. 57 389-407. 


\begin{tabular}{|c|}
\hline $\begin{array}{c}\text { APPENDIX 1 } \\
\text { Species list and updated nomenclature }\end{array}$ \\
\hline Taxon \\
\hline Achnanthes amoena Hustedt \\
\hline $\begin{array}{l}\text { Achnanthidium exiguum (Grun.) Czarn. } \\
\text { Achnanthes exigua Grun. in Cleve \& Grun. }\end{array}$ \\
\hline $\begin{array}{l}\text { Achnanthidium exiguum var.heterovalva (Krasske) Czarn. } \\
\text { Achnanthes exigua var.heterovalva Krasske }\end{array}$ \\
\hline $\begin{array}{l}\text { Achnanthidium minutissimum (Kütz.) Czarn. } \\
\text { Achnanthes minutissima Kütz. }\end{array}$ \\
\hline $\begin{array}{l}\text { Achnathidium microcephalum (Kütz.) vide Rabenh. } \\
\text { Achnanthes microcephala (Kütz.) Grun. }\end{array}$ \\
\hline Amphipleura pellucida Kütz. \\
\hline Amphora coffeaeformis (Agardh) Kütz. \\
\hline \begin{tabular}{|l|} 
Amphora montana Krasske \\
Amphora submontana Hustedt
\end{tabular} \\
\hline Amphora ovalis (Kütz.) Kütz. \\
\hline $\begin{array}{l}\text { Amphora pediculus (Kütz.) Grun. } \\
\text { Amphora ovalis var. pediculus (Kütz.) Van Heurk }\end{array}$ \\
\hline Amphora veneta Kütz. \\
\hline Anomoeoneis sphaerophora (Ehr.) Pfitzer \\
\hline $\begin{array}{l}\text { Aulacoseira granulata }(\text { Ehr.) Simonsen } \\
\text { Melosira granulata }(\text { Ehr.) Ralfs }\end{array}$ \\
\hline $\begin{array}{l}\text { Aulacoseira granulata var. angustissima (O.Müll.) Simonsen } \\
\text { Melosira granulata var. angustissima O.Müll. } \\
\end{array}$ \\
\hline $\begin{array}{l}\text { Aulacoseira italica (Ehr.) Simonsen } \\
\text { Melosira italica (Ehr.) Kütz. }\end{array}$ \\
\hline $\begin{array}{l}\text { Brachysira vitrea (Grunow) Ross in Hartley } \\
\text { Anamoneis exilis (Kütz.) Cleve }\end{array}$ \\
\hline Caloneis aequatorialis Hustedt \\
\hline Caloneis bacillum (Grun.) Cleve \\
\hline Caloneis schumanniana var. biconstricta (Grun.) Reichert \\
\hline $\begin{array}{l}\text { Caloneis silicula }(\text { Ehr.)Cleve } \\
\text { Caloneis ventricosa (Ehr. Donkin) Meister }\end{array}$ \\
\hline Cocconeis pediculus Ehr. \\
\hline Cocconeis placentula Ehr. \\
\hline $\begin{array}{l}\text { Craticula ambigua (Ehr.) Mann in Round, Crawford \& Mann } \\
\text { Navicula cuspidata var. ambigua (Ehr.) Cleve } \\
\end{array}$ \\
\hline $\begin{array}{l}\text { Craticula cuspidata (Kütz.) Mann in Round, Crawford \& Mann } \\
\text { Navicula cuspidata Kütz. }\end{array}$ \\
\hline Cyclotella meneghiniana Kütz. \\
\hline Cyclotella operculata (Agardh) Kütz. \\
\hline Cyclotella stelligera Cleve et Grun. in Van Heurk \\
\hline $\begin{array}{l}\text { Cymatopleura solea (Bréb.) W.Smith } \\
\text { Cymatopleura librile (Ehenberg) Pantocsek }\end{array}$ \\
\hline Cymbella amphicephala Naegeli \\
\hline Cymbella amphicephala var. hercynica (A.Schmidt) Cleve \\
\hline Cymbella aspera (Ehr.) Cleve \\
\hline Cymbella begalensis Cleve \\
\hline Cymbella cistula (Ehr.)Kirchner \\
\hline Cymbella kappii Cholnoky \\
\hline Cymbella kolbei Hustedt \\
\hline Cymbella turgida Gregory \\
\hline $\begin{array}{l}\text { Diadesmis confervacea Kütz. } \\
\text { Navicula confervaceae (Kütz.) Grun. }\end{array}$ \\
\hline $\begin{array}{l}\text { Diadesmis contenta var. biceps (Grun. ex V.Heurk) Mann in Round, } \\
\text { Crawford \& Mann } \\
\text { Navicula contenta Grun. }\end{array}$ \\
\hline Diploneis ovalis (Hilse) Cleve \\
\hline Diploneis smithii var. pumila (Grun.) Hustedt \\
\hline
\end{tabular}

\section{Diploneis subovalis Cleve}

Encyonema minutum (Hilse in Rabenhorst) Mann in Round,

Crawford \& Mann

Cymbella minuta Hilse ex Rabenhorst

Cymbella ventricosa Kütz.

Encyonema muelleri (Hustedt) Mann in Round, Crawford \& Mann

Cymbella muelleri Hustedt

Encyonopsis aequalis (W.Smith) Krammer

Cymbella aequalis W.Smith

Encyonopsis microcephala (Grun.) Krammer

Cymbella microcephala Grun.

Eolimna minima (Grun.) Lange-Bertalot

Navicula minima Grun.

Eolimna subminuscula (Manguin) Lange-Bertalot \& Metzeltin

Navicula subminuscula Manguin

Navicula frugalis Hustedt

Navicula perparva Hustedt

Fallacia pygmaea (Kütz.) Stickle \& Mann in Round, Crawford \&

Mann

Navicula pygmaea Kütz.

Fragilaria capucina Desmazieres

Synedra rumpens Kütz.

Fragilaria capucina var. acuta (Ehr.) Rabenhorst

Fragilaria capucina var. vaucheriae (Kütz.) Lange-Bertalot

Synedra vaucheriae Kütz.

Fragilaria construens (Ehr.) Grun.

Fragilaria delicatissima (W.Smith) Lange-Bertlot

Synedra acus var. radians (Kütz.) Hustedt

Frustulia rhomboides (Ehr.) De Toni

Frustulia vulgaris (Thwaites) De Toni

Geissleria decussis (Østrup) Lange-Bertalot \& Metzeltin

Navicula decussis Østrup

Navicula canoris Hohn \& Hellerman

Navicula exiguiformis Hustedt

Gomphonema clavatum Ehr.

Gomphonema clevei Fricke

Gomphonema gracile var. subcapitata Gandhi

Gomphonema gracile Ehr.

Gomphonema gracile var. lanceolata (Kütz.) Cleve

Gomphonema parvulum Kütz.

Gomphonema pumilum (Grun.) Reichardt \& Lange-Bertalot

Gomphonema intricatum var. pumila Grun. in V.Heurck

Gomphonema schweickerdtii Cholnoky

Gomphonema truncatum Ehr.

Gomphonema truncatum var. capitatum (Ehr.) Patrick

Gyrosigma nodiferum (Grun.) Reimer

Gyrosigma spencerii var. nodifera (Grun.) Cleve

Gyrosigma scalproides (Rabenhorst) Cleve

Gyrosigma spencerii (Quekett) Griffith

Hantzschia amphioxys (Ehr.) Grun. in Cleve \& Grun.

Hantzschia amphioxys var. africana Hustedt

Hippodonta capitata (Ehr.) Lange-Bertalot \& Metzeltin in

Witkowski

Navicula capitata Ehr

Hippodonta hungarica (Grun.) Lange-Bertalot \& Metzeltin in

Witkowski

Navicula hungarica Grun.

Kobayasiella subtilissima (Cleve) Lange-Bertalot

Navicula subtilissima Cleve

Lemnicola hungarica (Grun.) Round \& Basson

Achnanthes hungarica Grun. in Cleve \& Grun.

Luticola mutica (Kütz.) Mann in Round, Crawford \& Mann

Navicula mutica Kütz. 


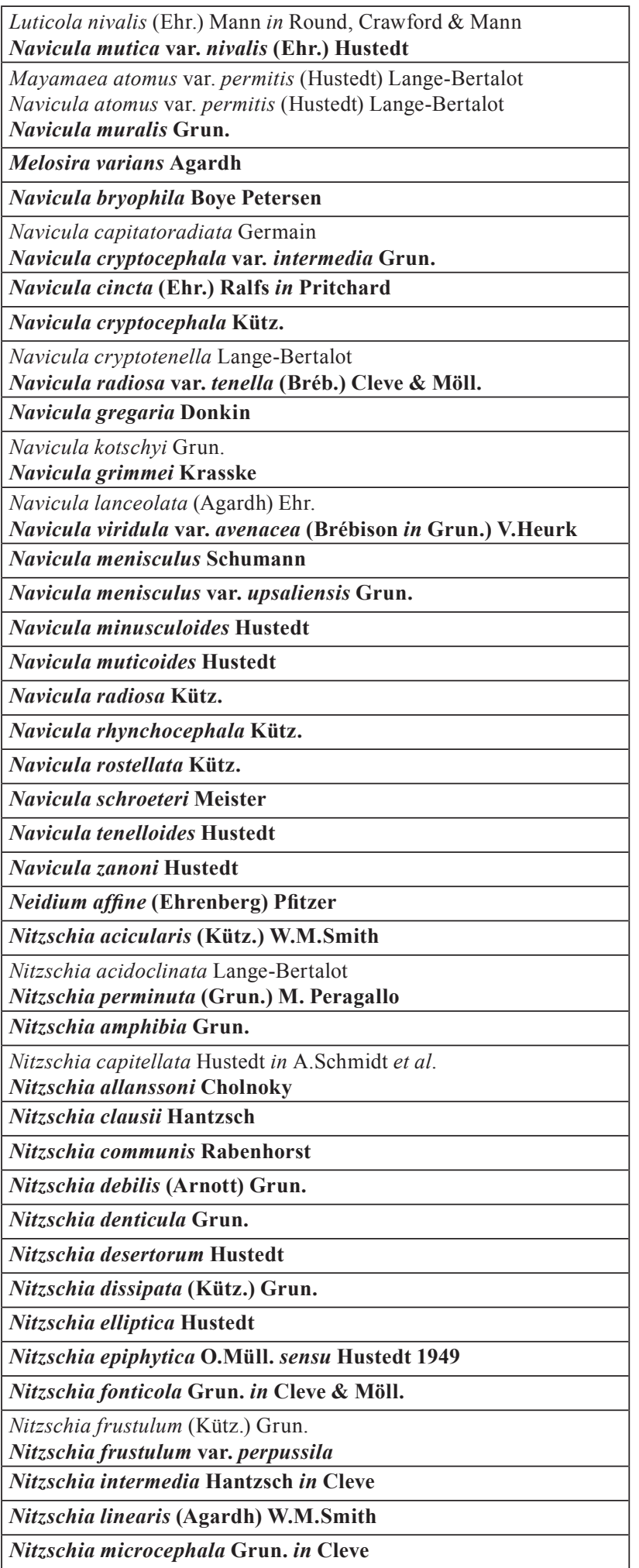

\begin{tabular}{|c|}
\hline $\begin{array}{l}\text { Nitzschia nana Grun. in V.Heurck } \\
\text { Nitzschia ignorata Krasske }\end{array}$ \\
\hline Nitzschia palea (Kütz.) W.Smith \\
\hline $\begin{array}{l}\text { Nitzschia paleacea (Grun.) Grun. in V.Heurk } \\
\text { Nitzschia bacata Hustedt }\end{array}$ \\
\hline Nitzschia parvuloides Cholnoky \\
\hline $\begin{array}{l}\text { Nitzschia pusilla (Kütz.) Grun. } \\
\text { Nitzschia kuetzingiana Hilse }\end{array}$ \\
\hline Nitzschia sigma (Kütz.) W.M.Smith \\
\hline Nitzschia sinuata var. tabellaria (Grun.) Grun. \\
\hline $\begin{array}{l}\text { Nitzschia solgensis Cleve-Euler } \\
\text { Nitzschia interurupta (Reichelt) Hustedt }\end{array}$ \\
\hline Nitzschia tropica Hustedt \\
\hline $\begin{array}{l}\text { Nitzschia umbonata (Ehr.) Lange-Bertalot } \\
\text { Nitzschia thermalis (Kütz.) Auerswald }\end{array}$ \\
\hline Pinnularia eburnea (Carlson) Zanon \\
\hline Pinnularia gibba Ehr. \\
\hline Pinnularia gibba var. sancta (Grun.) Meister \\
\hline Pinnularia interrupta W.M.Smith \\
\hline Pinnularia viridis (Nitzsch) Ehr. \\
\hline $\begin{array}{l}\text { Placoneis dicephala (W.Smith) Mereschkowsky } \\
\text { Navicula dicephala (Ehr.) W.Smith } \\
\text { Navicula dicephala var. neglecta (Krasske) Hustedt }\end{array}$ \\
\hline $\begin{array}{l}\text { Planothidium lanceolatum (Bréb.) Round \& Bukhitiyarova } \\
\text { Achnanthes lanceolata (Bréb.)Grun. }\end{array}$ \\
\hline Rhopalodia gibba (Ehr.) O.Müll. \\
\hline Rhopalodia gibberula (Ehr.) O.Müll. \\
\hline $\begin{array}{l}\text { Sellaphora pupula (Kütz.) Mereschkowksky } \\
\text { Navicula pupula Kütz. } \\
\text { Navicula nyassensis O.Müll. }\end{array}$ \\
\hline $\begin{array}{l}\text { Sellaphora seminulum (Grun.) Mann } \\
\text { Navicula seminulum Grun. }\end{array}$ \\
\hline Stauroneis anceps Ehr. \\
\hline $\begin{array}{l}\text { Staurosira construens var. venter (Ehr.) Hamilton } \\
\text { Fragilaria constuens f. venter (Ehr.) Hustedt }\end{array}$ \\
\hline $\begin{array}{l}\text { Staurosirella pinnata (Ehr.) Williams \& Round } \\
\text { Fragilaria pinnata Ehr. }\end{array}$ \\
\hline Stephanodiscus hantzschii Grun. in Cleve \\
\hline Surirella angusta Kütz. \\
\hline Surirella ovalis Bréb. \\
\hline Surirella tenera Gregory \\
\hline Synedra ulna (Nitzsch) Ehr. \\
\hline Tabellaria fenestrata (Lyngbye) Kütz. \\
\hline $\begin{array}{l}\text { Tryblionella apiculata Gregory } \\
\text { Nitzschia apiculata (Gregory) Grun. }\end{array}$ \\
\hline $\begin{array}{l}\text { Tryblionella hungarica (Grun.) Mann in Round, Crawford \& Mann } \\
\text { Nitzschia hungarica Grun. }\end{array}$ \\
\hline $\begin{array}{l}\text { Tryblionella levidensis W. Smith } \\
\text { Nitzschia levidensis (W.Smith) Grun. in V Heurk }\end{array}$ \\
\hline $\begin{array}{l}\text { Tryblionella victoriae Grun. } \\
\text { Nitzschia levidensis var. victoriae Grun. }\end{array}$ \\
\hline
\end{tabular}

